\title{
Trash Trade and Environmental Regulations: An Assessment
}

\author{
Shamila Dawood* \\ University of Colombo, Sri Lanka
}

\author{
Ajra Azhar \\ University of Colombo, Sri Lanka
}

\begin{abstract}
Following China's decision to ban trash import in 2018, some countries in Southeast Asia are at the forefront of banning and imposing stringent measures to crackdown trash trade. The new trend in trash trade regulations had further impacted weaker countries and made a haven for dumping waste unless they adopt a uniform mechanism to regulate or completely ban trash trade within the region. This study aimed to analyze the recent response of some developing countries to the trash trade and how likely this response impact other countries in the same region, by taking into account the impact of the trash trade on the environment and health and waste handling capacity. This study adopted doctrinal analysis that combined descriptive and analytical approaches to analyze trash trade and regulation impacts in developing countries and arrived at a need for a holistic approach and national waste management policy to encourage the recycling industry in trash receiving states. This study found that although developing countries had a perfect set of rules and norms regarding sustainable waste management and protecting illicit trash trade, most of them had shortages due to internal and external factors. Solid waste management in developing and least developed countries was a never-ending problem due to the low technological requirements and economic investments.
\end{abstract}

KEYWORDS: Trash Trade, Developing Countries, Environmental Justice.

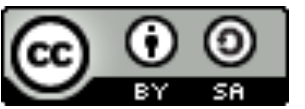

Copyright @ 2021 by Author(s)

This work is licensed under a Creative Commons Attribution-ShareAlike 4.0 International License. All writings published in this journal are personal views of the authors and do not represent the views of this journal and the author's affiliated institutions.

HOW TO CITE:

Dawood, Shamila \& Ajra Azhar, "Trash Trade and Environmental Regulations: An Assessment" (2021) 8:3 Lentera Hukum 347-386. DOI: <https://doi.org/ 10.19184/ejlh. v8i3.27138>.

Submitted: 18/09/2021 Reviewed: 21/09/2021 Revised: 29/11/2021 Accepted: 29/11/2021

\footnotetext{
*Corresponding author's e-mail: dlfshamila@gmail.com
} 


\section{INTRODUCTION}

International trade in industrial waste has grown faster than total trade$8.8 \%$ vs. $7.0 \%$, respectively, per year on average between 2002 and $2019 .{ }^{1}$ The European Union (EU) and North America are the world's main waste exporters, ${ }^{2}$ while the EU and Asia are the biggest importers. ${ }^{3}$ The global annual waste trade grew rapidly from 1993 and continued to grow exponentially in 2016. In 1993, the waste trade grew by $723 \%$, while in 2016, it grew by $817 \% .{ }^{4}$ Not all waste moves from developed to developing regions in a linear way, as waste trade clusters depend on commercial routes, reverse logistics, geographic proximity or trade agreements. ${ }^{5}$

Overall, unethical transboundary movements of wastes and their disposal drive developing countries into a more vulnerable position in responding to environmental crises. ${ }^{6}$ Some developing countries have taken measures to crackdown trash trade due to the quality of recyclate wastes export, managing and handling waste, lack of modern technology, and public pressure. For instance, in 2018, China declared a total ban on importing nonindustrial plastic waste. The following the China ban, like Malaysia, the Philippines, Vietnam, and Thailand are at the forefront of banning and imposing stringent measures to crackdown trash trade. It poses a more significant challenge for other developing countries in the same region either to adopt stringent mechanisms, regulate recycling industries, or completely ban the trash trade.

1 Manuel Albaladejo, et al., "What is the Circular Economy? (2021) Industrial Analytics Platform, online: <https://iap.unido.org/articles/what-circular-economy>.

2 Nanno Mulder, et al., "International Trade and the Circular Economy in Latin America and the Caribbean" (2021) Inclusive and Sustainable Industrial Development Working Paper Series ECLAC-UNIDO, Vienna.

3 Ibid.

4 Silpa Kaza, et al., What a Waste 2.0: A Global Snapshot of Solid Waste Management to 2050 (Washington DC: Urban Development Series World Bank, 2018).

5 Henrique Pacini \& Tze Ni Yeoh, "Success of The Circular Economy Hinges on Better Governance of 'Waste Trade',', online: <https://unctad.org/news/success-circulareconomy-hinges-better-governance-waste-trade $>$.

6 Anyinam CA, "Transboundary Movements of Hazardous Wastes: The Case of Toxic Waste Dumping in Africa" (1991) 21:4 International Journal of Health Services 759777. 
On the one hand, international instruments on transboundary movement like the Basel convention is not adequate embedded provision related to handling waste by source countries. ${ }^{7}$ It relates to the sovereignty concept, basically built on the prior informed consent procedure. For instance, Ajibo rightly argues that the procedure should be upgraded to meet the sound Environmental Impact Assessment standard. It entails evaluating the potential risk and ability, thus allowing the importing countries to make an informed decision. ${ }^{8}$ Accordingly, the problem should be addressed from domestic to international measures. On the other hand, developing countries should strengthen the domestic environmental law to regulate trash trade with impact assessment reports. Numerous researches have been done on hazardous transboundary movement and developing countries. ${ }^{9}$ However, little researches have been done on the trash trade and developing countries. ${ }^{10}$

This study argued that exporters should adhere to global environmental standards for admission to environmental markets may provide necessary incentives for developing countries to upgrade their environmental performance. Nevertheless, the trash trade should be analyzed from the industrial recycling perspective, domestic waste management policy, and the existing system. Many developing countries do not adopt an acceptable waste management policy, which creates a dilemma in regulating the trash trade. Thus, the current study focused on the issues faced by developing countries in handling trash trade and provide potential recommendations to the policymakers and the source countries' responsibilities in adhering to

7 Avitus A. Agbor, "The Ineffectiveness and Inadequacies of International Instruments in Combatting and Ending the Transboundary Movement of Hazardous Wastes and Environmental Degradation in Africa" (2016) 9:4 African Journal of Legal Studies 235-267.

8 Kenneth I. Ajibo, "Transboundary Hazardous Wastes and Environmental Justice: Implications for Economically Developing Countries" (2016) 18:4 Environmental Law Review 267-283.

9 Katharina Kummer, "Transboundary Movements of Hazardous Wastes at the Interface of Environment and Trade" (1994) United Nations Environmental Programme, 143159.

10 Zaida Lipman, "A Dirty Dilemma: The Hazardous Waste Trade" (2002) 23:4 Harvard International Review 67-71. 
the international environmental norms. It ensures a robust national policy on waste management to regulate the recycling industry. Otherwise, it prohibits the importation of trash.

This study aimed to analyze the recent response of some developing countries to the trash trade and how likely this response impact other countries in the same region. For this study, first, this study analyzes the impact of the transboundary movement in developing countries. Second, it analyzes the impact of trash trade under the environmental justice system and inter, and intragenerational perspectives. Third, the study emphasizes the international instruments and regional instruments relevant to developing countries' transboundary movement and the applicability and scope of such instruments. Finally, it proposes some recommendations for developing countries to adapt to manage trash within their territory.

\section{METHODS}

This study was a doctrinal analysis that included descriptive and analytical approaches. Data were collected mainly on primary and secondary resources, including international and regional instruments on transboundary movements on trash, were analyzed. These data supported the study that analyzed international instruments to revisit the provisions related to developing countries on trash trade, and the developed countries support establishing best practice approaches to minimize the harms during the transboundary movement of trash.

\section{TRANSBOUNDARY MOVEMENT OF TRASH AND DEVELOPING COUNTRIES}

The Economists of International Trade Waste claim that the last two decades show an unprecedented scale of hazardous and non-hazardous trade waste. ${ }^{11}$ According to Greenpeace, 'between 2016 and 2018, the ASEAN region saw plastic waste imports grow by a staggering $171 \% \ldots$

11 Derek Kellenberg, "The Economics of the International Trade of Waste" (2015) 7:1 Annual Review of Resource Economics 109-125. 
this equivalent to around 423,544 20-foot shipping containers.' It amounted to nearly two billion tons of waste dumped globally every year. ${ }^{12}$ The mounting transboundary solid waste causes severe impacts on the environment and health. Environmentalists argue that the collecting and disposing of a large volume of garbage creates now and future generations risks. For instance, new generation risks are immediate, such as nuisance risks-fire, odor, and vermin. Simultaneously, the second-generation problems, such as leachate, should be understood from the negative impacts of landfills. ${ }^{13}$ Leaking the toxic substance contaminates gradually into the ground that remains in our environment with the possibility of entering the food chain, including riverbanks. Long-term exposure to shredded plastics, which result from burning plastics, contains heavy metals such as cadmium and lead, which cause damage to the brain, nervous system (lead), and kidneys, lungs, and bones (cadmium). ${ }^{14}$ Low quality plastics exports and the lack of modern technology to handle recycling in developing countries also lead to improper waste storage and treatment systems; this dramatically impacts health and the environment due to new chemicals. ${ }^{15}$

The developing countries face numerous challenges on non-recyclable or low-quality plastics and scrap materials as secondary raw materials. Thus, some developing countries are at the forefront of banning and imposing stringent measures to crackdown trash trade. For instance, China has gradually introduced ways to minimize the importation of non-recyclable waste. In 2003, the operation of the 'Green Fence' movement was formally

12 The World Counts, "Tons of Waste Dumped Annually", online: <https://www. theworldcounts.com/challenges/planet-earth/state-of-the-planet/world-wastefacts/story>.

13 Alexander Gillespie, Waste Policy: International Regulation, Comparative and Contextual Perspectives, (Cheltenham: Edward Elgar Publishing Limited, 2015).

14 Greenpeace Malaysia, "Waste Trade Woes", online: <https://www.greenpeace.org/ malaysia/press/3367/waste-trade-woes/>. See also CHEM Trust, "No Brainer - The impact of Chemicals on Children's Brain Development: $A$ Cause for Concern and A Need for Action" online: <https://www.chemtrust.org/wp-content/uploads/chemtrustnobrainer-mar17.pdf $>$.

15 Pablo Cubel, "Transboundary Movements of Hazardous Waste in International Law: The Special Case of the Mediterranean Area" (1997) 12:4 The International Journal of Marine and Coastal Law 447-448. See also Greenpeace Malaysia supra note 14. 
implemented to curtail the number of contaminated recyclables and waste that were exported to China. It created an opportunity for the recycling industry and municipalities to evaluate policies and practices and adjust to changing markets. ${ }^{16}$ The Green Fence movement was implemented "to reduce any illegal shipments, improve the quality of the imported wastederived secondary raw materials, and minimize illegal trading within the country."17 In 2008, China issued an Announcement on Releasing the Catalogue of Solid Wastes Forbidden to Import Catalogue of Restricted Import Solid Wastes that Can Be Used as Raw Materials to support the recycling and manufacturing industries in China. China has been the biggest importer of plastic waste. ${ }^{18}$ In 2016, China received plastic waste from 43 countries out of 123 recyclable plastic export countries. Since 1992, China has imported 45 percent of all plastic waste. It shows China's ability to use the material for goods. Later, the poor quality of plastics being exported led to many health and environmental problems in China. ${ }^{19}$ Considering these consequences, in 2018, China declared a total ban on importing nonindustrial plastic waste. ${ }^{20}$

Under recyclable plastics, other rubbish, including body parts and nonrecyclable trash, is being exported into developing countries. Some South and East Asian Countries have become cautious about the importation of

16 Amy L. Brooks, et al., "The Chinese Import Ban and its Impact on Global Plastic Waste Trade" (2018) 4:6 Science Advances. See also Will Flower, "What Operation Green Fence has Meant for Recycling", online: <https://www.waste360.com/business/whatoperation-green-fence-has-meant-recycling $>$.

17 Costas Velis, "Global Recycling Markets - Plastic Waste: A Story for One Player - China" (2014) Report Prepared by FUELogy and Formatted by D-waste on Behalf of International Solid Waste Association - Globalisation and Waste Management Task Force. See also Michikazu Kojima, et al., Lessons Learned from The Illegal Transboundary Movement of Hazardous Waste in Asia. In International Trade in Recyclable and Hazardous Waste in Asia (Cheltenham: Edward Elgar Publishing, 2013).

18 Amy L. Brooks, et al. supra note 16.

19 Laura Parker and Kennedy Elliott, "Plastic Recycling Is Broken - Here's How to Fix It" online: <https://www.nationalgeographic.com/news/2018/06/china-plastic-recycling -ban-solutions-science-environment/>.

20 Amy L. Brooks, et al. supra note 16. 
waste after China's decision. Malaysia's, ${ }^{21}$ the Philippines's ${ }^{22}$, and Sri Lanka's ${ }^{23}$ recent action to repatriate the waste shipment to source countries such as the USA, Canada, and the UK is a prime example. Furthermore, Malaysia and Vietnam ceased issuing new permits or licenses for the importation of plastic waste. This alarms neighboring countries as some countries within the region bring more stringent mechanisms to counter waste management. The rest of the weaker countries become more hotspots for the waste dump. The regional or sub-regional legal agency should adapt to govern plastics and plastic products, regulate trash trade, and curb illegal importations.

Generally, developing countries use improper disposal of waste to cause further significant long-term consequences. For instance, disposal into the air through the burning of garbage is ordinary in some developing countries, nevertheless causing a severe impact on health and the environment. Illegal waste management collecting centers and dumping and using waste for recycling purposes cause a significant effect on society's well-being. Moreover, the ghost containers found in the ports of developing countries carry with post-consumer household waste such as used mattresses and carpets, plastic, and polythene scraps without the required prior permission as Articles 6 of the Basel Convention mandates. ${ }^{24}$ Increasingly, hazardous wastes exports are not only being disguised by waste traders but are also being exported openly for 'further use' such as

21 Penang, "Malaysia Sends Back Trash, Says Won't be World's Waste Bin", online: $<$ https://www.latimes.com/environment/story/2020-01-19/malaysia-sends-backtrash-says-it-wont-be-the-rubbish-dump-of-the-world>.

22 Ronn Bautista, "Philippines Sends Trash Back to Canada after Duterte Escalates Row", online: <https://www.reuters.com/article/us-philippines-canada-waste-idUSKCN1 T10BQ $>$.

23 Earth.Org, "Sri Lanka is Sending Hazardous Waste Back to the UK After a Two-Year Battle", online: <https://earth.org/sri-lanka-sending-hazardous-waste-back-to-the$\mathrm{uk} />$.

24 United Nations Environment Program, "Case of Illegal Traffic (Country Report BC10/13, $B C-11 / 10, B C-12 / 8$ and $B C-13 / 10)$ ", online: <http://www.basel.int/ Implementation/LegalMatters/IllegalTraffic/CasesofIllegalTraffic/tabid/3424/Defau 1t.aspx>. 
'waste to energy or 'recycling operations. ${ }^{25}$ By the early 1990s, some $90 \%$ of all hazardous waste exports to less-industrialized countries were headed for further use. ${ }^{26}$ For example, many waste trading firms have offered power plants to developing countries, including Sierra Leone, Belize, Angola, and Egypt, amongst many others, if they would in return accept hazardous waste as fuel to run the plant. The incineration of toxic waste, however, often creates even more dangerous toxins than the hazardous waste in its original form. ${ }^{27}$ Other recycling processes in underdeveloped countries have also been found to be harmful to both human health and the environment. $^{28}$ The Thor Chemicals mercury recycling factory in South Africa, which processes mercury waste supplied from Europe and North America, is one well-known example. Several employees at this plant have died as a result of mercury poisoning, while others have been permanently crippled. High quantities of mercury from the facility have also found their way into a nearby river, which the locals use for cooking and washing. ${ }^{29}$

China's import, and subsequent ban of trash trade, is based on commercial interest and the country's competitive advantage. It raises the question of what competitive advantage and technological advances other developing countries have to process the trash? The trash trade will not benefit unless it is regulated in an isolated area to promote recycling industries. However, it is doubtful how far these industries will succeed due to low-level law enforcement and the lack of modern technology and know-how. For instance, the waste hierarchy or the 4R concepts adopt to manage solid waste locally and globally, in the priority order - prevention, preparing for reuse, recycling, another recovery [i.e., energy recovery; and disposal]. ${ }^{30}$ In

25 Jennifer Clapp, "The Toxic Waste Trade with Less-Industrialized Countries: Economic Linkages and Political Alliances" (1994) 15:3 Third World Quarterly 505-518.

26 Interview with Jim Vallette, Greenpeace USA, Washington, DC, August 1993.

27 Jim Puckett, "Disposing of the Waste Trade" (1994) 24:2 The Ecologist. See also Jim Vallette and Heather Spalding, "The International Trade in Wastes: A Greenpeace Inventory" (Washington DC: Greenpeace International, 1990).

28 Jennifer Clapp, supra note 25.

29 Fred Kockott, "Wasted Lives: Mercury Waste Recycling at Thor Chemicals", (South Africa: Earthlife Africa and Greenpeace International, 1994).

30 Alexander Gillespie, supra note 13. See also Johan Hultman \& Herve Corvellec, "The European Waste Hierarchy: From the Socio Materiality of Waste to a Politics of 
reality, some scholars argue that the waste hierarchy is far from absolute. It has many theoretical difficulties in applying to different places, different scales of operation, and different types of waste. ${ }^{31}$

Although there are devastating reasons against trash trade in developing countries, researchers have discovered a potential bright side to this uneven trade as plastic waste may represent an economic boon for low-income countries. Bai et al. argue that "affluent countries outsource environmental burdens to developing countries. Another aspect of the tale is that plastic garbage could be used as a resource first, even if it ultimately adds to the environmental responsibilities of developing countries."32 Lipman's study highlights the importance of the trash trade to developing countries as it creates jobs by establishing secondary raw materials-related industries and thereby improves the quality of life. ${ }^{33}$ Further, the author quotes the importation of lead-acid batteries into India and the Philippines, which are required in their domestic sectors, such as batteries for automobiles, telecommunications, and computers. ${ }^{34}$

However, developing countries are not suitable for the trash trade, given the below explanation. The lack of infrastructure facilities, deficiency of resources to dispose of the waste safely and realistically, and the nonexistence of advanced technology in handling toxic waste are some main reasons that play a significant role. Furthermore, the lack of law enforcement, the lower economic cost in the exportation of trash, the lack of public protests in the careless waste disposal, and the lack of international regulations in transboundary hazardous waste monitoring systems are also contributing factors for the exportation of trash into

Consumption" (2012) 44:10 Sage Journals 2413-2427. See also Stijn Van Ewijk \& Julia Stegemann, "Limitations of The Waste Hierarchy for Achieving Absolute Reductions in Material Throughput" (2014) 132:19 Journal of Cleaner Production.

31 Pablo Cubel, supra note 15.

32 Yikang Bai \& Jennifer E. Givens, "Ecologically Unequal Exchange of Plastic Waste? A Longitudinal Analysis of International Trade in Plastic Waste" (2021) 27:1 Journal of World-Systems Research 265-287.

33 Zaida Lipman, supra note 10.

34 Ibid. 
developing countries. ${ }^{35}$ The poor become direct victims of massive environmental changes, including landfills. Shifting environmental burdens from one country to another violates environmental justice theory. It also leads to ecological outrages, such as air pollution, water pollution, an unhealthy environment, the spread of deadly diseases, stress, depression. Consequently, safeguarding the environment for the future becomes a great challenge for these countries. ${ }^{36}$

\section{TRANSBOUNDARY MOVEMENT OF WASTE, ENVIRONMENTAL JUSTICE THEORY, AND INTER AND INTRA GENERATIONAL EQUITY}

The environmental justice theory emphasizes the equitable distribution of environmental benefits and costs of people without any discrimination. ${ }^{37}$ The 'environmental justice' is defined as follows:

"Environmental justice is based on the principle that all have a right to be protected from environmental pollution and to live in and enjoy clean air. Environmental Justice is the equal protection and meaningful involvement of all people to the development, implementation, and enforcement of environmental laws, regulations and policies and the equitable distribution of environmental benefits." ${ }^{38}$

This definition exposes the main three aspects of environmental justice. Firstly, the procedural justice aspects concentrate on meaningful

35 Pablo Cubel, supra note 15.

36 Lisa Widawsky, "In My Backyard: How Enabling Hazardous Waste Trade of Developing Nations Can Improve The Basel Convention's Ability to Achieve Environmental Justice" (2008) 38:2 Environmental Law 577-625.

37 The term environmental justice first appeared in the 1980s, out of resistance to toxic facilities in black and other minority ethnic communities in the United States. A defining moment was the publication of research that reported that hazardous installations, such as toxic waste dumps, were often located in areas with higher percentages of people of color (UCC, 1987) cited in Keren Bell, Achieving Environmental Justice: A Cross-National Analysis (Bristol: University of Bristol, 2014) at 15.

38 Keren Bell, supra note 37. See also Julian Agyeman, Environmental Justice and Sustainable Development (New York: NYU Press, 2005) at 26. See also John Blewitt, Understanding Sustainable Development (UK \& USA: Earthscan, 2008) at 86. 
involvement of all people. Secondly, substantive justice aspects focus on the right to live in and enjoy a clean and healthy environment. Finally, distributive justice aspects stress equitable distribution of environmental benefits. ${ }^{39}$ These aspects of justice establish that a clean environment is an inherent right of the people. Upholding ecological justice in ecological management gives moral values of protecting the environment for present and future generations. Environmental justice identifies the unequal proportion of environmental risks, such as hazardous waste, dumps, unequal access to environmental goods (air and clean water), and less opportunity to participate in environmental decision-making. Poor people face more significant ecological risks and cannot control the environmental abuses imposed on them. ${ }^{40}$ The transboundary movements of hazardous waste and other waste without proper guidance on how to adopt a waste hierarchy system in developing countries import waste at the expense of its citizens' health and environmental risk.

Trash trade and dumping waste in developing countries are not adequately regulated, as discussed above. For instance, wealthier countries use the vulnerable situation of the developing countries to dump trash without supporting recyclates in line with the waste hierarchy or $4 \mathrm{R}$ concept. Source countries should not encourage landfilling or incineration of such recyclates in receiving countries.

Strengthening the environmental standards and preventing pollution is one of the core elements of the concept of sustainable development and underpin aims of inter, intra-generational equity and environmental justice. International communities distinguish responsibilities on environmental management; thus, principles like common but differentiated responsibilities emerge to accept the unequal status of countries in defining the role to adopt environmental sustainability. The international community recognized that developing countries need support from developed countries to encourage environmental sustainability at the

39 Julian Agyeman \& Bob Evans, "Just Sustainability: The Emerging Discourse of Environmental Justice in Britain?" (2004) 170:2 The Geographical Journal 155-164.

40 Kristin Shrader-Frechette, Environmental Justice: Creating Equality, Reclaiming Democracy (Oxford: Oxford University Press 2002) at 3. 
domestic level. In the trash trade, it is entirely different from other trade and investments. Some developing countries involve the trash trade to generate wealth either through reuse or disposal at the expense of environmental degradation. It involves complete trash, thus needing inordinate support from developed states or source countries to handle, reuse, and dispose of waste. Campbell rightly argues that countries that cannot meet the standard must either ban the import of the waste or rely on the principles for international cooperation and ask for assistance. Nevertheless, the exporting country maintains responsibility for the waste until it is completely disposed of. ${ }^{41}$

Environmental justice theories underline the three basic requirements of sustainable development-fairness, justice, and equity among people. These theories admit the necessity to protect and promote the environment. It is the bounden duty and trusteeship of the people living on Earth to leave it to posterity in the same condition, if not better. The current generation is an inter-generational collective occupying the planet earth whose resources and nature are not exploited or ruined through government activities. Unregulated waste dumping systems in developing countries create longterm detrimental effects on the environment and thereby cause severe health issues and undermine the basic norms of environmental sustainability. Justice, equity, and fairness are interwoven and assist in satisfying the goals of present and unborn generations, making this environment more productive in terms of economic development and creating a meaningful distribution of wealth, health, and all other benefits.

Rich countries export trash into developing countries with no preventive measures to handle waste or no waste policy adopted by the import states. The recent waste shipment from the USA, UK, and Canada claimed nonrecyclable waste being exported. Shifting the burden into another jurisdiction is unacceptable and violates fairness, justice, and equity. Every aspect of the international community and government activities must comply with the environmental regulations and principles usually focus on

41 Viola Blayre Campbell, "Ghost Ships and Recycling Pollution: Sending America's Trash to Europe" (2014) 12:1 Tulsa Journal of Comparative and International Law 215. 
intergenerational equity and intra-generational equity. ${ }^{42}$ Hayward states that "securing environmental protection, equity in distribution and justice for future generations have been explicitly linked together in the idea of sustainability." 43

Adherence to domestic and international environmental law and regulations and sustainable development norms is imperative, emphasizing the significance of impact assessment procedures. It distinguishes waste and non-waste, adopting preventive safety measures, and treating and handling waste without profound impact on the environment and the surroundings. From environmental justice, managing sensitive environmental projects must ensure the principle of justice in every aspect of the process. Marginalized and vulnerable people should not be the victims of recycling industries; their legal, natural, and moral rights should be ensured and protected - which the concept of justice underpinning. Justice has multiple facets: distributive justice, social justice, natural justice, ecological justice, green justice, economic justice. It shows the values of justice as part of policymaking or decision-making. ${ }^{44}$ Then, Stone observes that every substantial change in man and his environment calls for a re-examination of existing values in their application to new situations. ${ }^{45}$ It is also sometimes defined as 'environmental ethics.'

42 See generally, Julian Agyeman, Robbert D. Bullard, and Bob Evans, "Exploring the Nexus: Bringing Together Sustainability, Environmental Justice and Equity" (2002) 6:1 Space and Policy 77-90 at 85.

43 Tim Hayward, "Social and Legal Perspectives on Environmental Problems" in Tim Hayward and John O'Neill, Justice (eds.), Property and the Environment: Social and Legal Perspective Justice, Property and the Environment, Social and Legal Perspectives (Farnham: Ashgate Publishing Ltd, 1997) at 2. See also Discussions about sustainability frequently focus on the integrational implications of present decisions regarding resources depletion and investment. Christopher B. Barrett, "Commentary; Fairness, Stewardship and Sustainable Development" (1995) 19:1 Ecological Economics $11-17$ at 13.

44 Stephen Tromans, "High Talk and Low Cunning: Putting Environmental Principles into Legal Practice" (1995) Journal of Planning \& Environment Law. See also John Rawls, "Justice as Fairness" (1958) 67:2 The Philosophical Review 164-194.

45 Stone, Visions of World order-Between State Power and Human Justice (Baltimore: Johns Hopkins University Press, 1984) at 71, cited in Shyami Fernando Puvimanasinghe, Foreign Investment, Human Rights and the Environment; $A$ 
To maintain justice, fairness, and equity, full disclosure of environmentrelated issues at the negotiation stage is required to combat environmental degradation and minimize the negative impacts to fulfill the collective responsibilities towards conserving the environment. ${ }^{46}$ It allows contracting parties to undertake environmental mitigation according to their capabilities. Thus, Principle 24 of the Stockholm Declaration expresses this statement as;

"International matters concerning the protection and improvement of the environment should be handled in a cooperative spirit by all countries, big or small, on an equal footing. Corporation through multilateral or bilateral arrangements or other appropriate means is essential to effectively control, prevent, reduce and eliminate adverse environmental effects resulting from activities conducted by all spheres, in such a way that due account is taken of the sovereignty and interests of all State." ${ }^{47}$ (Emphasis added).

Nevertheless, the recent trash trade crisis reveals that rich countries export non-recyclable waste into developing countries. Allowing trash trade paves the way for the illegal importation of trade waste into developing countries.

\section{INTERNATIONAL LAWS ON TRANSBOUNDARY HAZARDOUS AND DEVELOPING COUNTRIES}

\section{A. The Basel Convention}

The Basel Convention is one of the pioneer international instruments drafted to protect developing countries from exploitation by developed countries. $^{48}$ The preamble recognizes the "increasing desire for the

Perspective from South Asia on the Role of Public International Law for Development (Leiden \& Boston, Martinus Nijhoff Publisher, 2007).

46 Basel Convention on the Control of Transboundary Movements of Hazardous Waste and Their Disposal (1989) UN Doc. UNEP/IG.80/3, 1673 U.N.T.S. 28911 [hereinafter Basel Convention].

47 The Declaration of the United Nations Conference on the Human Environment (1972) Chapter 2 Principles 8, 12, and 24. See also Michael Jacobs, Sustainable Development: A Contested Concept, in Andrew Dobson (ed.), Fairness and Futurity (Oxford: Oxford University Press, 1999) at 39.

48 The Basel Convention, supra note 48. 
prohibition of transboundary movements of hazardous wastes and their disposal in other States, especially developing countries." ${ }^{49}$ The Basel Convention recognizes the "state responsibility to handle hazardous waste movement and disposal is consistent with the protection of human health and the environment." Further, illustrate that the sovereign State has a right to ban the entry of foreign waste. As mentioned above, the developing countries have limited capabilities to manage variants of hazardous wastes exported into the nations.

The Basel Convention characterized plastic waste into several categories and regulated trash export. For instance, under the purview of the Basel Convention, if a 'plastic waste categorized under the waste requires special consideration,' then its export should be regulated. This Convention scrutinizes mechanisms to build capacity to properly manage plastic waste by providing a framework for knowledge sharing, promoting the proper management of waste, and including harmonization of technical standards. ${ }^{50}$ Strict liability is one of the appropriate legal concepts that could apply to controlling the trash trade. Waste producers and exporters should be liable and accountable for the material they produce and export that does not meet the international standard when shipping to other countries. Article 9, if any party contravenes the provisions of Basel Convention and is subject to any prohibited activities listed in the condition which are considered 'illegal trafficking.' The prohibited activities are generally attempting to dump hazardous waste in the states concerned without any notice, prior approval, or approval obtained from falsification/misrepresentations/ fraud. ${ }^{51}$

The Basel Convention enables the concerned country to report illegal trafficking by completing and transmitting table 9. Accordingly, Belgium, Brazil, Palestine, Sri Lanka have submitted their reports. ${ }^{52}$ In illegal trafficking, the waste in question will send back to the country of export, and it becomes impractical that the waste will dispose of as per the

$49 \quad$ Ibid.

50 Ibid.

51 Ibid.

52 Basel Convention (1989) a 3. 
provisions of the Convention. ${ }^{53}$ Widawsky analyzes how developing nations can improve the Basel Convention's ability to achieve environmental justice through enabling an innovative mechanism for the hazardous trash trade. The author claims as follows:

"Nor do developing countries have the financial resources to place the issue of hazardous waste importation high on their priority lists. Therefore, the exportation of toxic waste to the Third World is thoroughly grounded in the existing global economic structure. Until this global economic inequity is resolved, wealth will continue to permit industrialized nations to proclaim. ${ }^{54}$

The Conference of Parties (COP), as a governing body of the Basel Convention, made changes to the Convention on 1 January 2021. It adopted a control mechanism and a stricter approach to shipments of plastic scraps and waste intended for recycling or disposal internationally. ${ }^{55}$ New categories of plastic waste subject to the Convention emerged based on the recent amendments to the annexes to the Convention. ${ }^{56}$

Under this new amendment, most plastic scrap and waste, including hazardous and non-hazardous, are subject to Basel Convention, which should be bound to follow prior notice and consent requirements. ${ }^{57}$ The new Basel-controlled non-hazardous plastic scrap and the waste listing includes the following;

"The plastic scrap and waste that is contaminated (e.g., with food residue and/or other non-hazardous waste), mixed with other types of scrap and waste, containing halogenated polymers (e.g., PVC) and mixed plastic scrap and waste, except for shipments consisting of

53 Basel Convention (1989) a 9(2).

54 Lisa Widawsky, supra note 36. See also Marguerite M. Cusack, "International Law and the Transboundary Shipment of Hazardous Waste to the Third World: Will the Basel Convention Make a Difference?" (1990) 5:2 American University International Law Review 393-423.

55 Basel Convention (Amendments to Annexes II, VIII, and IX) Decision BC-14/12.

56 Basel Convention, supra note 48.

57 The Basel Convention (Amendments to Annexes II, VIII, and IX) supra note 58. 
polyethylene $(\mathrm{PE})$, polypropylene $(\mathrm{PP})$, and polyethylene terephthalate (PET) that meet the criteria described in Basel listing B3011." ${ }^{158}$

Howard advocates that the Basel Convention becomes an excellent platform for uniting more than hundreds of nations with diverse goals to reach an agreement on a contentious topic. ${ }^{59}$ However, in reality, hazardous waste is still being transported both lawfully and unlawfully. ${ }^{60}$ Article 04 of the Convention imposes general obligations for parties to the treaty.

\section{B. Bamako Convention}

The Basel Convention encourages parties to bring bilateral, multilateral, and regional agreements on hazardous waste. ${ }^{61}$ Accordingly, in January 1991, in Bamako, the twelve member nations of the Organization of African Union signed a treaty called the Bamako Convention on the Ban of the Import into Africa and the Control of the Transboundary Movements and Management of Hazardous Waste Within Africa. ${ }^{62}$ Eight years after the signing of the Bamako Convention, it came into effect as Africa faced two dangerous and noxious waste dumping incidents. ${ }^{63}$

Koko in Nigeria and Probo Koala in Ivory Coast are the two significant waste dumping incidents from the African region. In 1998, in Koko, Italian businessmen dumped large quantities of hazardous waste containers

58 Ibid.

59 Kathleen Howard, "The Basel Convention: Control of Transboundary Movements of Hazardous Wastes and Their Disposal" (1990) 14:1 Hastings International and Comparative Law Review 223.

60 J. Vallette, The International Trade In Wastes: A Greenpeace Inventory (1989) at 7. See also US Congress, Greenpeace Waste Trade Update (House Report, 2525 from the $101^{\text {st }}$ Congress, 1989) at 4.

61 Article 11 of the Basel Convention - Article 11 of the Convention provides, among other things, that Parties may enter into bilateral, multilateral, or regional agreements or arrangements regarding the transboundary movement of hazardous wastes or other wastes with Parties or non-Parties provided that such agreements or arrangements do not derogate from the environmentally sound management of hazardous wastes and other wastes as required by this Convention.

62 Bamako Convention on the Ban of the Import into Africa and the Control of Transboundary Movement and Management of Hazardous Waste Within Africa, adopted at Bamako, Mali on 30 January 1991. Bamako Convention (1991).

63 Bamako Convention, supra note 64. 
and drums in a small village in Southern Nigeria. It was claimed to be fertilizers to the farmer but caused severe health issues, including deaths through leaks in those containers and drums. Nearly 500 residents were evacuated, and people in the area remember the incident as "drums of death"- Koko. In Ivory Coast's Probo Koala case, in 2006, a Panamaregistered cargo ship hired by the commodities trading firm Trafigura spilled approximately 500 cubic meters of highly hazardous trash in Abidjan, killing 17 people and sickening tens of thousands more. ${ }^{64}$ Both of these incidents highlight the failure of the Basel Convention in regulating hazardous exportation in developing countries. ${ }^{65}$ Accordingly, the goals of the Convention are; to forbid the import of all kinds of hazardous; decrease and resist the transboundary movements of hazardous; to prohibit all hazardous waste disposal or combustion in the ocean and inland waterways; ensure the environmentally sound disposal of the waste; promote cleaner production over the pursuit of a permissible emissions approach and make the precautionary principle a reality. ${ }^{66}$

The Bamako Convention sets a standard based on covering most of the categories of waste that the Basel Convention did not cover. It includes radioactive waste, any waste with a listed hazardous characteristic or a constituent as dangerous waste. ${ }^{67}$ Moreover, waste consists of those severely restricted or subject to prohibitions. ${ }^{68}$ For instance, Article 4(1) ensures the banning of all kinds of s hazardous waste imports, and Article 4(2) prohibits dumping hazardous wastes at sea and internal waters. ${ }^{69}$

Further, waste generation in Africa carries some procedures to follow and rules to adhere to. The Bamako Convention mentioned those criteria in Article 4(3). Accordingly, each party shall ensure specific criteria such as waste generator should submit a report to the Secretariat to produce waste audit, impose liability, ensure adequate treatment and disposal facilities, prevent pollution, and safeguard human health and environment.

64 Trafigura [2016] C/13/581973 / HA ZA 15-195.

65 Penang, supra note 21.

66 Bamako Convention, supra note 65.

67 See, Article 2, Scope of the Convention, Bamako Convention, supra note 5.

68 Ibid., Article 2 (1) (d).

69 Ibid Article 4. 
Furthermore, precautionary measure is significant to avoid harm. It involves, among other things, preventing the release of substances into the environment that may harm people or the environment without first obtaining scientific proof of such harm. It ensures that each stakeholder should make every effort to adopt and execute a proactive, preventative strategy to pollution.

The primary question that one could raise is whether the provisions provided by the Bamako Convention are effectively implemented. In February 2021, Abidjan, Ivorian Capital, declared that immediate steps and effective procedures would take at the national and regional levels to implement the Bamako Convention properly. Following determination was highlighted by His Excellency Anne Desire Oulotto, Minister of Sanitation, Environment and Sustainable Development of Cote d'Ivoire and President of the COP-2 of the Bamako Convention, as follows:

"The Bamako Convention is an important instrument demonstrating Africans' will to protect their health and environment. It is an instrument that can help us have a Continent free of all forms of pollution. However, to achieve the objectives of the Convention, we need to double our efforts and continue to create more initiatives." ${ }^{70}$

\section{The Fourth Convention of Lome}

In December 1989, the African, Caribbean, and Pacific (ACP) nations agreed to include a provision banning the export of all hazardous and radioactive waste from the European Countries to any $\mathrm{ACP}$ state and prohibiting the import by the $\mathrm{ACP}$ countries from any country into the fourth revision of the Lome Convention (Lome IV). ${ }^{71}$ This particular

70 Abidjan, Parties committed to a pollution-free Africa Through the Implementation of the Bamako Convention (Africa: UNEP Press Release, 2018).

71 Fourth ACP-EEC Convention (with protocols, the final act, exchange of letters, minutes of signature, declaration of signature dated 19 December 1990, and Memorandum of Rectification dated 22 November 1990). Concluded at Lomé on 15 December 1989. [IV Lome Convention (1989)] Article 39(1). 
Convention defined the 'hazardous wastes' including the household wastes and incinerator residue based on Annex I and II of the Basel Convention. ${ }^{72}$ Promoting the socio-economic, cultural development of the ACP states is the ultimate objective of this Convention. In addition, it considers the establishment of "close cooperation in a spirit of complete equality and "just and equitable world economic order" by creating a model for relations between developing and developed countries. ${ }^{73}$ The significant change adopted under Lome IV is banning toxic waste movements between ACPs and EC member states and the increased EDF funding for the decentralized cooperation and diversification of the economy. Article 5 of the Lome IV incorporated a human rights clause as a 'fundamental' part of cooperation. It shows the Convention's flexibility in incorporating human rights - a vital element of cooperation and considered it the first development agreement to incorporate a human rights clause. It outlines that any violation could lead to a partial or total suspension of development aid by the European Union after prior consultation of other ACP nations and the abusing party, by the gravity of the human rights clause.

\section{The 1996 Protocol}

The 1996 Protocol on the Prevention of Pollution of the Mediterranean Sea by Transboundary Movements of Hazardous Waste and their Disposal entered into force in $2007 .{ }^{74}$ Parties commit to taking the necessary steps to avoid, mitigate, and eradicate contamination of the Protocol's covered area caused by transboundary movements and the disposal of hazardous wastes. They pledge to limit the creation of hazardous wastes and the transboundar $y$ transportation of hazardous wastes to a bare minimum, to

72 Ibid.

73 Kenneth O. Hall and Byron W. Blake, "The Emergence of the African, Caribbean, and Pacific Group of States: An Aspect of African and Caribbean International Cooperation" (1979) 22:2 African Studies Review 111-125.

74 Protocol on the Prevention of Pollution of the Mediterranean Sea by Transboundary Movements of Hazardous Wastes and their Disposal Adopted on 1 October 1996, in Izmir, Turkey entered into force 19/12/2007, online: <https://www.unep.org/unepmap/who-we-are/contracting-parties/hazardouswastes-protocol>. [Protocol 1996]. 
zero where practicable. They laid out steps to limit transboundary hazardous waste movements in the Mediterranean to safeguard the ecosystem. Additionally, they tried to eliminate such transport in the Mediterranean and restrict the shipment and transit of hazardous waste to emerging nations and parties that are not European Community member states and Monaco. ${ }^{75}$

Article 6 of this Protocol mentioned a fundamental structure and procedure for the transboundary movement of wastes. Additionally, the same article dealt with the notification procedures considered based on the Basel Convention. Article 10 of this Protocol describes the role of parties in case they are opted to assist the developing countries. This particular article in assistance to developing countries says that,

"While assisting to developing countries, the parties shall, directly or with the assistance of competent or other international organizations or bilaterally, cooperate in formulating and implementing programs of financial and technical assistance to developing countries for the implementation of this Protocol." ${ }^{176}$

\section{REGULATING TRASH TRADE: RECOMMENDATIONS}

\section{A. Waste Policy}

A sound national-level waste policy is imperative to encourage trash trade for economic benefits. The goal of waste policy should be to reduce the negative impacts of waste creation and management on human health and the environment as much as possible. Primarily, waste policies should be concentrated more on reducing waste generation, reusing the waste generated, and recycling the waste. The waste policy should also strive to minimize resource consumption and promote implementing the waste hierarchy in practice. If all of these elements are scrutinized while drafting the waste policies, that will lead to a sustainable waste disposal policy. In addition, waste policies could also provide a complete guideline with a

75 Ibid Article 5.1-4. Also see Pablo Cubel, supra note 15.

76 Protocol 1996, supra note 76 at 10. 
written procedure for collecting, storing, processing, and disposing of trash generated and, of course, trash traded for disposal.

Waste management is critical for creating sustainable and habitable communities, yet many developing countries and cities struggle with it, i.e., Indonesia, ${ }^{77}$ China, ${ }^{78}$ Vietnam, ${ }^{79}$ Pakistan, ${ }^{80}$ Morocco ${ }^{81}$ and Burkina Faso. ${ }^{82}$ Waste management is costly, accounting for 20 to 50 percent of municipal budgets. Operating this critical municipal function necessitates developing integrated systems that are efficient, long-lasting, and socially beneficial.

In December 2018, Australia's Environment Ministers and the Australian Local Government Association President agreed on a National Waste Policy. The theme that focused on the policy was "Less Waste, More Resources." 83 This national policy standard set a new unified direction for trash disposal and recycling in Australia but also, to 2030, it establishes a

77 Environmental and Social Management Framework, Indonesia - Improvement of Solid Waste Management to Support Regional and Metropolitan Cities Project (Washington, DC: World Bank, 2019).

78 World Bank Group, "China: 3 Million to Benefit from Improved Solid Waste Management in City of Ningbo", online: <https://www.worldbank.org/en/news/pressrelease/2013/05/31/china-3-million-to-benefit-from-improved-solid-wastemanagement-in-city-of-ningbo $>$.

79 World Bank Group, "Can Tho Urban Development and Resilience Project for Vietnam", online: <https://projects.worldbank.org/en/projects-operations/project-detail/P1528 51?lang=en $>$.

80 World Bank Group, "Pakistan: Lahore Composting Project", online: $<$ https://projects.worldbank.org/en/projects-operations/project-detail/P106652?lang $=$ en>.

81 World Bank Group, "Morocco, A Trash Picker Cooperative Fights Climate Change", online: <https://www.worldbank.org/en/news/video/2016/02/16/in-morocco-atrashpicker-cooperative-fights-climate-change $>$.

82 The World Bank Group, "Urban Environment Project", online: $<$ https://projects.worldbank.org/en/projects-operations/project-detail/P000297?lang $=$ en>.

83 Australian Government and Australian Local Government Association, "National Waste Policy Action Plan", online: <https://www.environment.gov.au/system/files/ resources/5b86c9f8-074e-4d66-ab11-08bbc69da240/files/national-waste-policyaction-plan-2019.pdf>. See also Mark Esposito, Terence Tse \& Khaled Soufani, "Introducing a Circular Economy: New Thinking with New Managerial and Policy Implications" (2018) 60:3 California Management Review 5-19. 
framework for collaborative, national action on waste management, recycling, and resource recovery. ${ }^{84}$ Further, this 2018 National Policy of Australia represents new methods of thinking about rubbish as a resource and incorporates circular economy ideas into waste management to encourage better and more frequent use of our resources. The circular economy waste policies include improving recourse recovery, increasing recycled products, safeguarding human health, the environment, and the economy, and improving the information system. ${ }^{85}$ However, the authorities must assess the success of waste management policies to determine whether the outcomes achieved match policy aims and identify impediments and develop implementation strategies.

There is a considerable difference between the effectiveness of policy implementation in developed and developing countries. Let us consider the policy outcome evaluation of a developing country. It has most probably failed to accomplish the policy targets for various reasons, such as lack of implementation strategies, poor infrastructure facilities in the landfills, failure of the municipal waste generation, inadequate systems for recyclability. Moreover, significantly deficient sanitary landfills do not cope with modern engineering as developed countries design and construct.

This study draws examples from two developing countries relevant to their waste management policies, structures, and functioning based on their available infrastructure and technology.

In 2010, Brazil designed a virtuous National Solid Waste Policy System (PNRS) based on its legislation and programs. This policy was based on the 'polluter pays principle, a central component of the law, and it also inserted reverse logistics. Exclusively it applies to "(a) pesticides, hazardous waste, and associated packaging; (b) batteries; (c) tires; (d) lubricating oils and their packaging; (e) fluorescent bulbs, sodium and mercury vapor bulbs, and mixed-light bulbs; and (f) electronic products and 
components." 86 It was a cross-cutting law intended to reduce the overall volume of garbage produced across the country and improve the long-term viability of solid waste management from the local to the national level. ${ }^{87}$

In July 2019, at the 6th International Conference on Energy and Environment Research, it was discussed that although PNRS established a different set of rules and procedures regarding waste disposal, trash trade, recycling, and reusing, it has failed in its implementation phase. The evolution of solid urban waste management in Brazil was not successful for various reasons. The identified low evolution concerned four basic management processes: generation, collection, selective collection, and final disposal of waste. ${ }^{88} \mathrm{We}$ can depict that the implementation of the waste policy plays a crucial role in its successful application.

Sri Lanka, a developing country, is another appropriate example for its waste mismanagement and non-adaptation of proper mechanisms. The Metro Colombo Solid Waste Management Project (MCSWM) - a sanitary landfill site at Aruwakkalu in Puttalam District, Sri Lanka, was thought to be an economically feasible and viable solution for the longterm issue of Municipal Solid Waste disposal of the Colombo Metropolitan Area. Unfortunately, during the implementation stage, it caused environmental repercussions and socio-ecological calamity to the Puttalam population as the chosen location was non-suitability for the Sanitary Landfill. ${ }^{89}$ The authorities have ignored the ecological importance while selecting the Aruwakkadu landfill site. ${ }^{90}$ For instance, threats to human settlements and livelihood sites such as fisheries communities, potential tourism, households, demolishing the archeological or geological

86 US-Brazil Joint Initiative on Urban Sustainability, "Brazilian National Sild Waste Policy", online: <https://archive.epa.gov/international/jius/web/html/brazilian_ national_solid_waste_policy.html>.

87 Ghesla Pamela L., et al, "Municipal Solid Waste Management From the Experience of São Leopoldo/Brazil and Zurich/Switzerland" (2018) 10:10 Sustainability.

88 I.M. Costa \& M. Ferreira Dias, "Evolution on the Solid Urban Waste Management in Brazil: A Portrait of the Northeast Region" (2019) 6:1 Science Direct 22-25.

89 Environmental Impact Assessment Report, Sri Lanka (2017), s 3.2.0.

90 Environmental Impact Assessment Document of the MCSWM Project, s 3.2.2.6.4. 
importance are significant reasons to halting the project. ${ }^{91}$ Besides, some activists are skeptical about the Aruwakkadu landfill site because they suspect it could dump foreign garbage. ${ }^{92}$

Waste management is a national issue for Sri Lanka. However, it is not advisable to use the above-proposed site as a sanitary landfill in the long run due to its sensitivity. At the same time, it would create environmental catastrophe as having caused irreversible damage if it continued to be in progress. It is better to consider the recycling system inside the landfill cells without dumping the solid waste into layers.

By considering a couple of examples, the authors recommend some effective practical solutions that we should adhere to while drafting the waste management policies. First of all, Management of Waste Policy effectiveness evaluation is important for determining if the outcomes achieved match the policy aims, identifying barriers, and developing implementation methods. After the enactment and implementation of the Waste policies, the relevant entities or bodies should do an empirical statistical analysis over the period to evaluate whether municipal waste management key performance indicators improved or not. They must examine substantial improvements in metrics such as municipal trash generation, garbage collection frequency, recyclable waste recovery rate, and sanitary landfill share. When we cannot avoid trash generation, we all have a responsibility to play in attempting to reduce waste as much as possible while also making practical use of our garbage as resources. It is essential for the environment's, economies, and our own well-being's survival and sustainability.

91 Ranjeev Epa, et al., "An Abstract of a Relevant Paper on the Deposits at Aruwakkalu" (2011) 40:2 Ceylon Journal of Science 163-174.

92 News First, "Aruwakkalu and Importing Garbage Connected?", online: <https:// www.newsfirst.lk/2019/07/30/aruwakkalu-and-importing-garbage-connected/>. See also Sunday Observer, "Activists Suspect Attempts to Dump UK Garbage in Aruwakkalu", online: <http://www.sundayobserver.lk/2019/08/04/news/activistssuspect-attempts-dump-uk-garbage-aruwakkalu>. 


\section{B. Common but Differentiated Responsibility}

The principle of common but differentiated responsibility (CBDR) results from the evolution of two concepts such as common concern and shared heritage of humankind. ${ }^{93}$ The principle of CBDR is a result of the application of equity in international law and raising global awareness that developing countries have special needs, which must be taken into account when rules of international law are set, applied, and interpreted. ${ }^{94}$ Equal obligations cannot impose on all countries the same way; they need to consider countries' capacity to fulfill obligations to protect the environment. ${ }^{95}$ The principle consists of two main elements: first, it requires all States to take part in international response measures concerning environmental challenges; second, it implies countries with differing commitments and obligations, depending on their capacity, contribution to problems, and developmental needs. ${ }^{96}$ The role of the principle of CBDR in international legal instruments that apply to waste management and trash trade should be critically viewed on how international legal tools are used to the distribution of responsibility between states.

The Basel Convention does not directly apply the common but differentiated approach. However, it refers to the special needs of developing states. ${ }^{97}$ The Convention recognizes the lower capacity of such states to meet the requirements applied by the Convention and the need to

93 Vito De Lucia, "Common but Differentiated Responsibility" Encyclopedia of Global Warming \& Climate Change, Philander G.,(ed.) 'Thousand Oaks' (2012) SAGE Publications at 2.

94 Philippe Sands \& Jacqueline Peel, Principles of International Environmental Law (Cambridge: Cambridge University Press, 3rd ed, 2012) at 244.

95 Thomas Deleuil, "The Common but Differentiated Responsibilities Principle: Changes in Continuity After the Durban Conference of the Parties" (2012) 21:3 Review of European, Comparative \& International Environmental Law 271.

96 Tuula Honkonen, The Common but Differentiated Responsibility Principle in Multilateral Environmental Agreements (Alphen aan den Rijn: Kluwer Law Internasional, 2009) at 1.

97 Ibid. 
support their technical capabilities by developed states, which are more technically advanced. ${ }^{98}$

The Convention on Persistent Organic Pollutants refers directly to the common but differentiated responsibility and respective capabilities of developed and developing countries. ${ }^{99}$ The Preamble of the above Convention directs the parties to the Convention as follows;

Taking into account the circumstances and particular requirements of developing countries, in particular, the least developed among them, and countries with economies in transition, especially the need to strengthen their national capabilities for the management of chemicals, including through the transfer of technology, the provision of financial and technical assistance and the promotion of cooperation among the Parties, ${ }^{100}$

All nations' policy coherence for sustainable development (PCSD) initiatives should adhere to the CBDR concept to revitalize the global partnership for sustainable development. ${ }^{101} \mathrm{PCSD}$ is a policy instrument and a method for integrating the economic, social, environmental, and governance elements of sustainable development at all domestic and international policy formulation levels. ${ }^{102}$

The principle of CBDR favors the least advantaged States, which usually applies to developing States. In practice, the principle pursues by differentiated allocation of rights and obligations and redistribution of resources. ${ }^{103}$ Overall, the concept of common but differentiated responsibility determines two legal consequences: it creates a dual standard

98 Basel Convention, supra note 48, arts., 10 and 11.

99 Stockholm Convention on Persistent Organic Pollutants (2001) is an international environmental treaty, signed in 2001 and effective from May 2004.

100 Ibid, at Preamble.

101 Ye Jiang, "The CBDR Principle in the UN 2030 Agenda for Sustainable Development" (2016) 2:2 World Century Publishing Corporation and Shanghai Institutes for International Studies China Quarterly of International Strategic Studies 169-184.

102 Ernesto Soria Morales, "Policy Coherence for Sustainable Development in the Post 2015 Framework" (2014) Presentation at the EU PCD Focal Points Meeting.

103 Tuula Honkonen, supra note 99. 
favoring developing states and applies responsibility to developed states to assist developing states. ${ }^{104}$

Though it is well presented in legal instruments, the developed states failed to consider the different needs of developing states. The least developed countries are contributing to environmental degradation through mismanagement of hazardous waste. The European Environment Agency estimates that between 250,000 and 1.3 million tons of old electrical items are exported from the EU each year, primarily to West Africa and Asia. These commodities may then be processed in hazardous and inefficient ways, endangering local people's health and hurting the environment. ${ }^{105}$

High-income or advanced developed countries can develop sound waste management systems as they have enough capacity. Also, they can provide technological support for developing states as well. Nevertheless, unfortunately, they tend to trade waste to countries with lower income, which contribute most of the pollution and environmental degradation, specifically at a national level first and to the entire globe in the long run. "Developed countries should collaborate closely with developing countries in the future to avert potential environmental harm, boost commerce, and avoid further misunderstanding. Countries unable to achieve the criteria must prohibit trash imports or rely on international cooperation principles and seek help. Nonetheless, the trash remains the responsibility of the exporting country until it is entirely disposed of."106 Thus, it is the responsibility of trash exporting and importing countries to ensure that the after-importation process does not harm the environment as a precondition for importation.

\footnotetext{
${ }^{104}$ Yoshifumi Tanaka, Chapter 2: Principles of International Marine Environmental Law, (Cheltenham: Edwar Elgar Publishing, 2015) at 50.

105 John Vidal, "Toxic E-Waste Dumped in Poor Nations, Says United Nations", online: $<$ https://ourworld.unu.edu/en/toxic-e-waste-dumped-in-poor-nations-says-unitednations $>$.

106 Viola Blayre Campbell, supra note 43.
} 


\section{No Harm Policy}

Customary international law widely recognizes this principle. Nor harm principle simply means a state has a responsibility to avoid, mitigate, and regulate environmental harm to other states. ${ }^{107}$ According to the United Nations Charter and International Law principles, states have the sovereign right to use their resources according to their environmental and development policies and plans. It is also on them to ensure that activities within their jurisdiction or control do not harm the environment of other countries or regions outside of national authority. ${ }^{108}$

The most common judicial example mentioned in conjunction with the noharm rule involves a Canadian smelter whose sulfur dioxide emissions caused air pollution damage in the United States across the border. ${ }^{109}$ In that dispute, an arbitral panel found that the Canadian government was liable for damages caused by the smelter, particularly to land along the Columbia River valley in the United States. In Trail Smelter, Arbitration found that,

"According to principles of international and the law of the United States, when the matter is of extreme significance, and the harm is proven by clear and compelling evidence, no State has the right to use or authorize the use of its territory in such a way as to cause injury by fumes in or to the territory of another, or the possessions or persons within." 110

The no-harm rule has also been included in several legal and policy texts. According to Principle 21 of the Stockholm Declaration of 1972:

"States have, under the Charter of the United Nations and the principles of international law, the sovereign right to exploit their resources according to their environmental policies, and the responsibility to ensure that activities within their jurisdiction or

107 Ian Brownlie, Principles of Public International Law (7th edn) (Oxford: Oxford University Press, 2008). See Patricia Birnie, Alan Boyle \& Catherine Redgwell, International Law and the Environment (3rd edn) (Oxford: Oxford University Press, 2009).

108 Rio Declaration, principle 6.

109 Trail Smeter Case, United States v Canada [1938] [1941] 3 p 1905 - 1982.

110 Ibid. 
control do not cause damage to the environment of other States or areas beyond the limits of national jurisdiction."111

Principle 2 of the 1992 Rio Declaration on Environment and Development, article 3 of the Convention on Biological Diversity, and Article 8 of the United Nations Framework Convention on Climate Change (UNFCCC) reiterate principle 21 of the Stockholm Declaration. ${ }^{112}$ Besides, Article 194(2) of the United Nations Convention on Law of Sea (UNCLOS) ${ }^{113}$ outlines that states shall take all measures necessary to ensure that activities under their jurisdiction or control are so conducted as not to cause damage by pollution to other States and their environment. ${ }^{114}$ Based on this assessment, it is pretty clear that no harm policy is well established in international law.

Although these laws, policies, and procedures are already set, the critical question is whether the no-harm rule is used in real-world situations to reflect customary international law and whether the presence of the rule has been authoritatively acknowledged by the International Court of Justice (ICJ). The ICJ expressly declared in its advisory judgment on the threat or use of nuclear weapons that,

"The presence of a general responsibility of states to guarantee that activities under their jurisdiction and control respect the environment of other states or regions beyond national control has now become part of the corpus of international environmental law."115

111 Rio Declaration, principle 21.

112 Rio Declaration, principle 2; United Nations Framework Convention on Climate Change 1992, preamble, recital 8; Convention on Biological Diversity 1992, a 3; United Nations Convention on the Law of the Non-navigational Uses of International Watercourses 1997, a 7; Convention to Combat Desertification 1994, preambles, Convention on Persistent Organic Pollutants, 2001 and International Tropical Timber Agreement 2006.

113 United Nations Convention on the Law of the Sea 1982.

114 United Nations Convention on the Law of the Sea 1982, a 194(2).

115 Advisory Opinion on the Legality of the Threat or Use of nuclear weapons [1996] ICJ Reports, para 29, p 226, online: <http://www.icj-cij.org>. 
The court repeated the same findings in the following cases Hungary v. Slovakia ${ }^{116}$ and Argentina v. Uruguay. ${ }^{117}$

International Law Commission's (ILC) Draft Articles on Prevention of Transboundary Harm from Hazardous Activities ${ }^{118}$ Establishes some potential components for nations to adopt the no-harm principle to minimize or diminish inter-and intra-transboundary harm caused by hazardous activities. ${ }^{119}$ The legal literature increasingly sees the idea of prevention as stemming from the concept of due diligence - a standard of care for government officials—based on the ILC's work. ${ }^{120}$ The significant elements of due diligence include - the opportunity to act or prevent; foreseeability or knowledge that a specific activity could lead to transboundary damage; and proportionality in the choice of measures required to prevent harm or minimize risk." ${ }^{\text {"121 }}$

A State may be judged negligent and possibly responsible for the harm caused if appropriate actions to preserve the environment were not adopted, notwithstanding the foreseeability of events. ${ }^{122}$ First, each State must investigate the use of three tools, emphasizing their relevance in defining the type of harm, conducting environmental impact assessments, consulting local communities, and ensuring minimal environmental flows. Second, governments should adopt a preventative approach to damage by clarifying the responsibility to take necessary actions to prevent and reduce risks arising from notice and consultation duties. Finally, the authors recommend that every State follow the main facets of the no-harm rule defined by the recent finding in 2020 through an analysis of six emblematic

116 Hungary v. Slovakia [1997] ICJ Reports, para 53, p 41.

117 Argentina v. Uruguay [2010] ICJ Reports, para 101, p 1, 38.

118 International Law Association, Legal Principles Related to Climate Change, (Draft Committee Report, 2012) online: <http://www.ilahq.org/en/committees/index.cfm/ cid/1029>.

119 Ibid.

120 Patricia Birnie, Alan Boyle and Catherine Redgwell, supra note 99.

121 Ibid.

122 International Law Association, supra note 121. 
cases. ${ }^{123}$ Tignino and Bréthaut, in their studies identifies significant facets of the "no harm" principle by analyzing six landmark cases on the environment. ${ }^{124}$ These were brought before the ICJ and arbitration tribunal to avoid the significant harm posed by transboundary waste disposal. ${ }^{125} \mathrm{It}$ was well established by the dispute settlement mechanism by addressing the "no-harm" principle, which is a developing concept that encompasses various topics and includes numerous factors in its description. ${ }^{126}$

National sovereignty and sector-based perspectives ${ }^{127}$ does both Trail Smelter identify the first facet? ${ }^{128}$ and Lake Lanoux case. ${ }^{129}$ Environmental concerns and consideration of multiple scales is the second facet framed based on the verdict of the Gabčíkovo-Nagymaros case. ${ }^{130}$ This particular aspect was not based on the sector-based view; judges in their verdict expect governments to focus on their vigilance and preventive duties to reduce the danger of environmental damage. Correspondingly, they emphasize fair and acceptable water usage ideas, which indicate a desire to foresee potential damages and set conditions for cooperation among neighboring nations. The third facet includes both the Pulp Mills ${ }^{131}$ and

123 Mara Tignino \& Christian Bréthaut, "The Role of International Case Law in Implementing The Obligation not to Cause Significant Harm" (2020) 20 International Environmental Agreements: Politics, Law and Economics 631-648.

124 Ibid.

125 Nicaragua v. Costa Rica [2015] ICJ Reports 665.

${ }_{126}$ Mara Tignino \& Christian Bréthaut, supra note 126.

127 Ibid. Verdicts are made to protect national territories, and states are required not to influence the territory of others significantly. A sector-based viewpoint emerges from the judgments examined. The predominant concept is those operations that may cause harm should be continued with reasonable precautions to avoid potential repercussions on another state's territory. Apart from the environmental repercussions, this facet mainly focuses on sovereignty and territorial integrity.

128 Trail Smelter Case (the US v. Canada) [1938 and 1941], Reports of International Arbitration Awards, III, 1905-1982, analyzed in Maria Tignino \& Christian Bréthaut supra note 126.

129 Lake Lanoux case (Spain v. France) [1957] Reports of International Arbitration Awards, XII, 281-317; see, Maria Tignino \& Christian Bréthaut supra note 126.

130 Gabčíkovo-Nagymaros case (Hungary v. Slovakia) [1997] ICJ Reports, 7 analyzed in Maria Tignino \& Christian Bréthaut supra note 126.

131 Pulp Mills case (Argentina v. Uruguay) [2010] ICJ Reports, 14; See Maria Tignino \& Christian Bréthaut supra note 126. 
Kishenganga cases. ${ }^{132}$ It stressed the need to use three key instruments to explain the nature of the harm and first conduct an Environmental Impact Assessment, second consult local communities, and third, ensure that minimal environmental flows are met. These three instruments aid in the formulation of processes and the foreseeing of potential transboundary impacts. Finally, based on the judgments of the San Juan River cases, ${ }^{133}$ the fourth facet declared formalizing a preventive perspective on harm. The ICJ added notice and consultation as two new obligations in this facet and EIA procedures established in the third facet. The two responsibilities of notice and consultation enable this by framing decision-making and operational procedures and ensuring early transboundary conversations about potential consequences and methods to resolve them.

\section{CONCLUSION}

The study concentrates more on the developing countries regarding their solid waste mismanagement and trading trash for a temporary benefit without looking at long-term haphazard. Although they have a perfect set of rules and norms regarding sustainable waste management and protecting illicit trash trade, most developing countries have shortages due to internal and external factors. Solid waste management in developing and least developed countries is a never-ending problem due to the low technological requirements and economic investments.

The developed nations and all relevant stakeholders should join hands together to provide a viable solution to this transboundary waste disposal which occurs illegally and improperly. Mere enactments of laws, regulations, or directives are insufficient without having suitable implantation strategies such as appropriate recycling methods with new technology and innovative investment plans. Source countries should introduce feasible joint projects for developing countries to eliminate this

132 Kishenganga case (Pakistan v. India) [2013] Reports of International Arbitration Awards XXXI, 1-358.

${ }^{133}$ Nicaragua v. Costa Rica [2015] supra n.114; Nicaragua v. Costa Rica [2018] ICJ Reports cited in Maria Tignino \& Christian Bréthaut supra note 126. 
environmental contamination and health issues. Authorities and actors should prioritize waste management considering the global issues and should not compromise with sustainable waste management at any cost.

\section{ACKNOWLEDGMENTS}

None.

\section{COMPETING INTERESTS}

The authors declared that they have no competing interests.

\section{REFERENCES}

Abidjan, Parties Committed to a Pollution-free Africa through the Implementation of the Bamako Convention (Africa: UNEP Press Release, 2018).

Agbor, Avitus A., "The Ineffectiveness and Inadequacies of International Instruments in Combatting and Ending the Transboundary Movement of Hazardous Wastes and Environmental Degradation in Africa" (2016) 9:4 African Journal of Legal Studies.

Agyeman, Julian., Environmental Justice and Sustainable Development (New York: NYU Press, 2005).

Agyeman, Julian, and Bob Evans, "Just Sustainability: The Emerging Discourse of Environmental Justice in Britain?" (2004) 170:2 The Geographical Journal.

Agyeman, Julian, Robbert D. Bullard \& Bob Evans, "Exploring the Nexus: Bringing Together Sustainability, Environmental Justice and Equity" (2002) 6:1 Space and Policy.

Ajibo, Kenneth I., "Transboundary Hazardous Wastes and Environmental Justice: Implications for Economically Developing Countries" (2016) 18:4 Environmental Law Review.

Australian Government and Australian Local Government Association, 'National Waste Policy Action Plan' (2019). 
Bai, Yikang and Jennifer E. Givens, "Ecologically Unequal Exchange of Plastic Waste? A Longitudinal Analysis of International Trade in Plastic Waste" (2021) 27:1 Journal of World-Systems Research.

Bautista, Ronn, "Philippines Sends Trash Back to Canada after Duterte Escalates Row" online: <https://www.reuters.com/article/us-philippines -canada-waste-idUSKCN1T10BQ $>$.

Bell, Keren, Achieving Environmental Justice; A Cross-National Analysis (Bristol: University of Bristol, 2014).

Birnie, Patricia, Alan Boyle, \& Catherine Redgwell, International Law and the Environment (3rd edn) (Oxford: Oxford University Press, 2009).

Brooks, Amy L., et al., "The Chinese Import Ban and its Impact on Global Plastic Waste Trade" (2018) 4:6 Science Advances.

Brownlie, Ian, Principles of Public International Law (7th edn) (Oxford: Oxford University Press, 2008).

Campbell, Viola Blayre, "Ghost Ships and Recycling Pollution: Sending America's Trash to Europe" (2014) 12:1 Tulsa Journal of Comparative and International Law.

CHEM Trust, "No Brainer - The Impact of Chemicals on Children's Brain Development: A Cause for Concern and A Need for Action", online: $<$ https://www.chemtrust.org/wp-content/uploads/chemtrustnobrainer-mar17.pdf $>$.

Christopher B. Barrett, "Commentary; Fairness, Stewardship and Sustainable Development" (1995) 19:1 Ecological Economics.

Clapp, Jennifer, "The Toxic Waste Trade with Less-Industrialized Countries: Economic Linkages and Political Alliances" (1994) 15:3 Third World Quarterly 505-518.

Costa, I.M. \& M. Ferreira Dias, "Evolution on the Solid Urban Waste Management in Brazil: A Portrait of the Northeast Region" (2019) 6:1 Science Direct.

Cubel, Pablo, "Transboundary Movements of Hazardous Waste in International Law: The Special Case of the Mediterranean Area" (1997) 12:4 The International Journal of Marine and Coastal Law.

Cusack, Marguerite M., "International Law and the Transboundary Shipment of Hazardous Waste to the Third World: Will the Basel Convention Make 
a Difference?" (1990) 5:2 American University International Law Review.

Dawood, Shamila, "The Principle of CBDR in BITs to Promote Sustainable Development Strategies while Combating Environmental Degradation: A Developing Country Perspective" in Gammage C and Novitz T (eds.) Sustainable Trade, Investment, and Finance Toward Responsible and Coherent Regulatory Frameworks (Cheltenham: Edward Elgar, 2019).

Deleuil, Thomas, "The Common but Differentiated Responsibilities Principle: Changes in Continuity after the Durban Conference of the Parties" (2012) 21:3 Review of European, Comparative \& International Environmental Law.

Earth.org, "Sri Lanka is Sending Hazardous Waste Back to the UK After a Two-Year Battle", online: <https://earth.org/sri-lanka-sendinghazardous-waste-back-to-the-uk/>.

European Parliament and the Council of 19, Waste and Repealing Certain Directives (Directive 2008/98/EC).

Epa, Ranjeev, et al., "An Abstract of a Relevant Paper on the Deposits at Aruwakkalu" (2011) 40:2 Ceylon Journal of Science.

Ernesto Soria Morales, "Policy Coherence for Sustainable Development in the Post 2015 Framework" (2014) Presentation at the EU PCD Focal Points Meeting.

Fred Kockott, "Wasted Lives: Mercury Waste Recycling at Thor Chemicals" (South Africa:Earthlife Africa and Greenpeace International, 1994)

Ghesla, Pamela L., et al., "Municipal Solid Waste Management from the Experience of São Leopoldo/Brazil and Zurich/Switzerland" (2018) 10:10 Sustainability.

Gillespie, Alexander, Waste Policy: International Regulation, Comparative and Contextual Perspectives (Cheltenham: Edward Elgar Publishing Limited, 2015).

Greenpeace Malaysia, "Waste Trade Woes", online: <https:// www.greenpeace.org/malaysia/press/3367/waste-trade-woes/>.

Greenpeace Southeast Asia, "Policy Brief: Southeast Asia's Struggle Against the Plastic Waste Trade" online: <https://www.greenpeace.org/ 
southeastasia/publication/2559/southeast-asias-struggle-against-theplastic-waste-trade/>.

Honkonen, Tuula, The Common but Differentiated Responsibility Principle in Multilateral Environmental Agreements (Alphen aan den Rijn : Kluwer Law International, 2009).

Howard, Kathleen, "The Basel Convention: Control of Transboundary Movements of Hazardous Wastes and Their Disposal" (1990) 14:1 Hastings International and Comparative Law Review 223.

Hultman, Johan \& Herve Corvellec, "The European Waste Hierarchy: From the Socio Materiality of Waste to a Politics of Consumption" (2012) 44:10 Sage Journals.

International Law Association, Legal Principles related to Climate Change (Draft Committee Report, 2012).

Jacobs, Michael, Sustainable Development: A Contested Concept, in Andrew Dobson (edt) Fairness and Futurity (Oxford: Oxford University Press, 1999).

Jiang, Ye, "The CBDR Principle in the UN 2030 Agenda for Sustainable Development" (2016) 2:2 World Century Publishing Corporation and Shanghai Institutes for International Studies China Quarterly of International Strategic Studies.

Kaza, Silva, et al., A Global Snapshot of Solid Waste Management to 2050 (Washington, DC: Urban Development Series World Bank, 2018).

Kaza, Silva, et al., What a Waste 2.0: A Global Snapshot of Solid Waste Management to 2050 (Washington, DC: Urban Development Series World Bank, 2018).

Kellenberg, Derek, "The Economics of the International Trade of Waste" (2015) 7:1 Annual Review of Resource Economics.

Kummer, Katharina, "Transboundary Movements of Hazardous Wastes at the Interface of Environment and Trade" (1994) United Nations Environmental Programme.

Kojima, Michikazu, et al., "Lessons learned from the illegal transboundary movement of hazardous waste in Asia." In International Trade in Recyclable and Hazardous Waste in Asia (Cheltenham: Edward Elgar Publishing, 2013). 
Ladapo, Oluwafemi Alexander, "The Contribution of Cartoonists to Environmental Debates in Nigeria: The Koko Toxic-Waste-Dumping Incident" (2013) 1 RCC Perspectives.

Laura Parker \& Kennedy Elliott, "Plastic Recycling Is Broken - Here's How to Fix It", online: <https://www.nationalgeographic.com/news/2018/06/ china-plastic-recycling-ban-solutions-science-environment/>.

Lipman, Zaida, "A Dirty Dilemma: The Hazardous Waste Trade" (2002) 23:4 Harvard International Review.

Lucia, Vito De, "Common but Differentiated Responsibility" Encyclopedia of Global Warming \& Climate Change, Edited by Philander G., 'Thousand Oaks' (2012) SAGE Publications.

Mulder, Nanno, et al., "International Trade and the Circular Economy in Latin America and the Caribbean" (2021) Inclusive and Sustainable Industrial Development Working Paper Series, 3 ECLAC-UNIDO, Vienna.

Pacini, Henrique \& Tze Ni Yeoh, "Success of The Circular Economy Hinge on Better Governance of 'Waste Trade" (2021) UNCTAD 2021.

Penang, "Malaysia Sends Back Trash, Says Won't be World's Waste Bin", online: <https://www.latimes.com/environment/story/2020-01-19/ malaysia-sends-back-trash-says-it-wont-be-the-rubbish-dump-ofthe-world $>$.

Puckett, Jim, "Disposing of the Waste Trade" (1994) 24:2 The Ecologist.

Rawls, John, "Justice as Fairness" (1958) 67:2 The Philosophical Review.

Sands, Philippe \& Jacqueline Peel, Principles of International Environmental Law (Cambridge: Cambridge University Press, 3rd ed, 2012).

Shrader-Frechette, Kristin, Environmental Justice; Creating Equality, Reclaiming Democracy (Oxford: Oxford University Press, 2002).

Sonak, Sangeeta, Mahesh Sonak, \& Asha Giriyan, "Shipping Hazardous Waste: Implications for Economically Developing Countries" (2008) 8 International Environmental Agreements.

The World Counts, "Tons of Waste Dumped Annually", online: <https:// www.theworldcounts.com/challenges/planet-earth/state-of-theplanet/world-waste-facts/story>. 
Tignino, Maria \& Christian Bréthaut, "The Role of International Case Law in Implementing the Obligation Not to Cause Significant Harm" (2020) 20 International Environmental Agreements.

Tim Hayward, "Social and Legal Perspectives on Environmental Problems" in Tim Hayward and John O'Neill, Justice (eds.), Property and the Environment; Social and Legal Perspective Justice, Property and the Environment, Social and Legal Perspectives (Farnharm: Ashgate Publishing Ltd, 1997).

Tromans, Stephen, "High Talk and Low Cunning: Putting Environmental Principles into Legal Practice" (1995) Journal of Planning \& Environment Law.

United Nations Environment Program, Case of Illegal Traffic (Country Report BC-10/13, BC-11/10, BC-12/8 and BC-13/10).

United Nations Sustainable Development, Conference on Environment $\mathcal{E}^{\circ}$ Development: Agenda 21 (1992) Chapter 38.

U.S. Brazil Joint Initiative on Urban Sustainability, "Brazilian National Sild Waste Policy" (2010) Policy Review.

Vallette, Jim \& Heather Spalding, The International Trade in Wastes: A Greenpeace Inventory (Washington, DC: Greenpeace International, 1990).

Van Ewijk, Stijn \& Stegemann, Julia, "Limitations of The Waste Hierarchy for Achieving Absolute Reductions in Material Throughput" (2014) 132:19 Journal of Cleaner Production.

Velis, Costas, "Global recycling markets - plastic waste: A story for one player China" (2014) Report prepared by FUELogy and formatted by Dwaste on behalf of International Solid Waste Association Globalisation and Waste Management Task Force.

Vidal, John, "Toxic E-Waste Dumped in Poor Nations, Says United Nations", online: <https://ourworld.unu.edu/en/toxic-e-waste-dumped-in-poornations-says-united-nations $>$.

Widawsky, Lisa, "In My Backyard: How Enabling Hazardous Waste Trade of Developing Nations Can Improve The Basel Convention's Ability to Achieve Environmental Justice" (2008) 38:2 Environmental Law. 
Will Flower, "What Operation Green Fence has Meant for Recycling" online: $<$ https://www.waste360.com/business/what-operation-green-fencehas-meant-recycling>.

World Bank Group, "Can Tho Urban Development and Resilience Project for Vietnam" (2014) The World Bank Press Release.

World Bank Group, "China: 3 Million to Benefit from Improved Solid Waste Management in City of Ningbo" (2013) The World Bank Press Release.

World Bank Group, "Morocco, a Trash picker Cooperative Fights Climate Change" (2016) The World Bank Press Release.

World Bank Group, "Pakistan: Labore Composting Project" (2008) The World Bank Press Release.

World Bank Group, "Urban Environment Project" (2005) The World Bank Press Release. 